\title{
Low Dose Dapsone Therapy in Lepromatous Leprosy
}

\author{
A. B. A. KARAT \\ St. Catherine's Hospital, Birkenhead, England
}

\begin{abstract}
Under the conditions of this study, dapsone in doses of $5 \mathrm{mg}$ and $10 \mathrm{mg}$ daily when administered to patients with lepromatous leprosy is an ineffective therapy in terms of killing and elimination of Myco. leprae from human skin and bone marrow. A real danger of facilitating the emergence of resistant bacilli exists. Therefore, until there is more evidence from long term therapeutic trials of low dose dapsone in bacillated types of leprosy, conventional dosage of dapsone is recommended.
\end{abstract}

Clinicians treating lepromatolis leprosy patients before and after the iniroduction of sulphones as specific therapy have gained the impression that both the incidence and severity of erythema nodosum leprosum reactions in leprosy have greatly increased. There have been reports of the beneficial effects of low dose DDS in reducing the incidence of these reactions in lepromatous leprosy. The apparently effective inhibition of multiplication of Myco. leprae in the footpads of mice by extremely low concentrations of dapsone in the diet (of the order of $0.0001 \mathrm{~g} \%$ ) (Shepard et al., 1966) had tended to breed an undue sense of optimism and confidence in the efficacy of homeopathic doses in man. This optimism was further compounded by extrapolation of reported changes in Morphological Index of Myco. leprae in skin smears to death of Myco. leprae.

A study was initiated to elucidate the precise relationship between dose of dapsone and incidence of reactions, as well as the period of viability of Myco. leprae in skin and bone marrow of lepromatous leprosy patients on low and high dose of dapsone.

\section{Material and Methods}

Thirty consecutive untreated lepromatous leprosy patients were randomly allocated to three therapy groups:

(1) dapsone $5 \mathrm{mg}$ daily;

(2) dapsone $10 \mathrm{mg}$ daily;

(3) dapsone $100 \mathrm{mg}$ daily.

Skin smears were taken from 8 standard sites by slit-skin method once a month and Morphological Index (Shepard and McRae, 1965) and Bacterial Index (Ridley, 1964) were determined. Skin biopsy and bone marrow aspiration were obtained immediately prior to initiation of treatment and once in 3 months during the first year and once in 6 months for 2 subsequent years. Myco. leprae homogenates from these specimens were injected into hind footpads of thymectomized CBA mice which were harvested at regular intervals and harvest 
counts obtained. Clinical records included specific reference to occurrence of ENL, painful neutritis, iritis or any other intercurrent complication. The reactions were treated with 4 week course of 15 to $30 \mathrm{mg}$ of prednisolone.

Of the 30 patients only 15 patients -5 in each group-completed the study and the data regarding these patients is presented here.

\section{Results}

\section{Morphological Index}

In the majority of cases the MI was between 3 and $10 \%$ at initiation of treatment and came down to below $1 \%$ in 12 to 24 weeks in all the groups. There was no significant difference in rate of fall of MI between the low and the high dose group.

\section{Bacterial Index}

(a) $100 \mathrm{mg}$ dapsone. There was a fairly uniform fall in $\mathrm{BI}$ at the rate of $1+$ per year. Three of the 5 patients were skin smear negative at the end of 3 years. However, in 4 of the 5 patients bone marrow aspirates continued to be positive for Myco. leprae.

(b) $10 \mathrm{mg}$ dapsone. In 1 patient the $\mathrm{BI}$ fell at the same rate as that seen in patients in $100 \mathrm{mg}$ dapsone. In 2 patients there was no significant change in BI and in 2 patients there was a gradual rise in BI throughout the period of therapy despite the MI remaining persistently below the $0.1 \%$ in these cases.

TABLE 1

Dapsone $10 \mathrm{mg}$ daily

\begin{tabular}{ccc}
\hline \multicolumn{3}{c}{ Changes in BI over 3 years } \\
\hline Steady fall & No change & Gradual rise \\
1 & 2 & 2 \\
\hline
\end{tabular}

(c) $5 \mathrm{mg}$ dapsone. There was a steady fall in $\mathrm{BI}$ in 1 patient, no change in 1 patient and a gradual rise in 3 patients.

TABLE 2

Dapsone 5 mg daily

\begin{tabular}{ccc}
\hline \multicolumn{3}{c}{ Changes in BI over 3 years } \\
\hline Steady fall & No change & Gradual rise \\
1 & 1 & 3 \\
\hline
\end{tabular}

$E N L$

Two patients in each of the 3 therapy groups developed ENL and there was no clinically recognizable difference between the 3 groups. 


\section{Bacilli in the bone marrow}

Except for 1 patient on $100 \mathrm{mg}$ dapsone whose skin smear also had become negative at 2 years, in all the other patients AFB was demonstrable in bone marrow aspirates throughout the period of study.

\section{Viability of Myco. leprae in skin and bone marrow while on therapy}

(a) $100 \mathrm{mg}$ dapsone daily. In all patients, Myco. leprae from skin biopsy homogenates were non-viable in footpads of mice between 6 and 12 months of treatment with dapsone $100 \mathrm{mg}$ daily. In 2 the Myco. leprae from bone marrow became non-viable at 24 months, in 1 at 30 months, in 1 at 36 months; while in 1 it was viable at the end of 36 months.

TABLE 3

Viability of Myco. leprae in skin and bone marrow of patients treated with dapsone $100 \mathrm{mg}$ daily

\begin{tabular}{|c|c|c|c|c|c|c|c|c|c|c|c|}
\hline \multirow{2}{*}{ Time } & \multirow{2}{*}{ Site } & \multicolumn{2}{|c|}{1} & \multicolumn{2}{|c|}{ II } & \multicolumn{2}{|c|}{ III } & \multicolumn{2}{|c|}{ IV } & \multicolumn{2}{|c|}{ V } \\
\hline & & $S$ & BM & S & BM & $S$ & BM & $S$ & BM & $\mathrm{S}$ & $\mathrm{BM}$ \\
\hline 0 & & + & + & + & + & + & + & + & + & + & + \\
\hline 3 months & & + & + & + & + & + & + & + & + & + & + \\
\hline 6 months & & - & + & + & + & - & + & + & + & + & + \\
\hline 9 months & & - & + & + & + & - & + & - & + & + & + \\
\hline 12 months & & - & + & - & + & - & + & - & + & _ & + \\
\hline 18 months & & - & + & - & + & - & + & - & + & - & + \\
\hline 24 months & & - & - & - & + & - & - & - & + & - & + \\
\hline 30 months & & - & - & - & + & - & - & - & - & - & + \\
\hline 36 months & & - & - & - & - & - & - & - & - & - & + \\
\hline
\end{tabular}

(b) $10 \mathrm{mg}$ dapsone daily. In 1 patient the bacilli from the skin became non-viable at 18 months and in another at 36 months while in the rest of the 3 patients the bacilli were still viable at 36 months. However, in all the patients the bacilli from the bone marrow remained viable at 36 months.

TABLE 4

Viability of Myco. leprae in skin and bone marrow of patients treated with dapsone $10 \mathrm{mg}$ daily

\begin{tabular}{|c|c|c|c|c|c|c|c|c|c|c|c|}
\hline & \multirow{2}{*}{ Site } & \multicolumn{2}{|c|}{ I } & \multicolumn{2}{|c|}{ II } & \multicolumn{2}{|c|}{ III } & \multicolumn{2}{|c|}{ IV } & \multicolumn{2}{|c|}{ V } \\
\hline Time & & S & BM & $\mathrm{S}$ & BM & S & BM & S & BM & S & BM \\
\hline 0 & & + & + & + & + & + & + & + & + & + & + \\
\hline 3 months & & + & + & + & + & + & + & + & + & + & + \\
\hline 6 months & & + & + & + & + & + & + & $\dot{t}$ & + & + & + \\
\hline 9 months & & + & + & + & + & + & + & + & + & + & + \\
\hline 12 months & & + & + & + & + & + & + & + & + & + & + \\
\hline 18 months & & - & + & + & + & + & + & + & + & + & + \\
\hline 24 months & & - & + & + & + & + & + & + & + & + & + \\
\hline 30 months & & - & + & + & + & + & + & + & + & + & + \\
\hline 36 months & & - & + & + & + & + & + & - & + & + & + \\
\hline
\end{tabular}


(c) $5 \mathrm{mg}$ dapsone daily. In 1 patient the bacilli from the skin became non-viable at 18 months and in another at 36 months. In none of the patients the bacilli from the bone marrow attained non-viability at the end of 36 months (Table 5).

TABLE 5

Viability of Myco. leprae in skin and bone marrow of patients treated with dapsone $5 \mathrm{mg}$ daily

\begin{tabular}{|c|c|c|c|c|c|c|c|c|c|c|c|}
\hline \multirow{2}{*}{ Time } & \multirow{2}{*}{ Site } & \multicolumn{2}{|c|}{1} & \multicolumn{2}{|c|}{ II } & \multicolumn{2}{|c|}{ III } & \multicolumn{2}{|c|}{ IV } & \multicolumn{2}{|c|}{ V } \\
\hline & & S & BM & $\mathrm{S}$ & BM & S & BM & S & BM & S & BM \\
\hline 0 & & + & + & + & + & + & + & + & + & + & + \\
\hline 3 months & & + & + & + & + & + & + & + & + & + & + \\
\hline 6 months & & + & + & + & + & + & + & + & + & + & + \\
\hline 9 months & & + & + & + & + & + & + & + & + & - & + \\
\hline 12 months & & + & + & + & + & + & + & + & + & & + \\
\hline 18 months & & + & + & + & + & + & + & + & + & & + \\
\hline 24 months & & + & + & + & + & - & + & + & + & - & + \\
\hline 30 months & & + & + & + & + & - & + & + & + & & \\
\hline 36 months & & + & + & + & + & $\ldots$ & + & + & + & & - \\
\hline
\end{tabular}

\section{Comments}

(1) There is no evidence to show that ENL reactions can be reduced by reduction of dosage of dapsone. The occurrence of reactions in lepromatous leprosy seems to follow an "all or none" law as far as dapsone is concerned.

(2) Morphological Index, under the conditions of these experiments, appears to be an unreliable measure of viability of Myco. leprae.

(3) Dapsone when administered orally in dosage of $100 \mathrm{mg}$ daily, renders the Myco. leprae in human skin non-viable in 6 to 12 months. However, a significant lag period exists between killing of Myco. leprae in skin and in bone marrow, the latter being viable for 12 to 24 months after the bacilli in the skin are dead.

(4) Dapsone when administered in daily doses of $5 \mathrm{mg}$ and $10 \mathrm{mg}$ over a 3 year period is far less effective in both killing and eliminating Myco. leprae from skin and bone marrow.

\section{Acknowledgement}

It is a pleasure to acknowledge the support for this study from Radda Barnen, Stockholm. I am grateful to Mr Rajan Albert and Mr S. Kumar for technical assistance.

\section{References}

Ridley, D. S. (1964). Leprosy in Theory and Practice 2nd ed. (Eds R. G. Cochrane and T. F. Davey), p. 620. Bristol: John Wright \& Sons Ltd.

Shepard, C. C. and McRae, D. H. (1965). J. Bact. 89, 365.

Shepard, C. C., McRae, D. H. and Hebas, J. A. (1966). Proc. Soc. exp. Biol. Med. 122, 893. 